\title{
Bricolage concept in risk culture assessment
}

\author{
Iwona Gorzeń Mitka ${ }^{1}$, PhD
}

\begin{abstract}
:
When faced with challenging conditions in which companies operate today, rapid access to various forms of resource can be a key determinant of organisational resilience on risk. Management of risk is considered to be a powerful instrument for sustainable development in organization. The concept of bricolage offers the potential to better understanding of organisational resourcefulness in a time of disruption. The study includes the research results concerning the identification of correlations between bricolage and the attitude as to risk as a key element of forming the risk management culture in the practice of Polish small and medium sized enterprises from the point of view of a balanced development. An additional goal of this research is to, at least partially, fill the gap in researches in terms of risk management. The research findings indicate that an approach to decision processes in the context of bricolage and an attitude towards risk are indeed dependent of one another.
\end{abstract}

Key words: bricolage, management, environment, decision-making processes, risk culture

\section{Introduction}

Running a competitive business in modern conditions requires the businessmen to analyze many, and often interdependent factors. However, as T.Baker and R.Nelson (2005) show a large portion of businesses (mainly from the small and medium size enterprise sector) focus their actions mainly on the owned resources and achieved profits in a short-time perspective. They rarely search for chances generated by the market, overlooking the importance of strategic planning. Such a formulation of the efficiency of their actions is possible due to their natural flexibility in terms of adjusting in the event of a change in the functioning factors, and the ability to use new resources when these become available (Okręglicka, Gorzeń-Mitka, Ogrean 2015, Haviernikova 2014). It's also needed to be stressed out, that such an approach to running a business is related to accepting a high level of uncertainty. The concept including the above mentioned characteristics of modern entrepreneurship is bricolage which, as Di Domenico, Haugh, and Tracey (2010) show, in case of insufficient resources and a flexible approach to the conditions in which the enterprise functions, allows to create an added value.

The bricolage concept has been initially used to describe the hermetization of the processes of the hybridization of culture (meaning a description of specific behaviors in closed societies) by Claude Levi-Strauss (1969) in 1962. It concerned the description of the actions of a community which - from a collection of elements of the owned resources, sometimes strange and heterogeneous, collected according to the imperative principle "it might come in handy" - has the ability to mobilize its practical knowledge in 
a different way than might be suggested by the general theoretical indications determining how the resources should be used.

A number of bricolage definitions may be found in literature (the author has discussed it widely in Gorzeń-Mitka 2015a). And so Ciborra (1996, 2002) among others, uses the concept of bricolage to describe "mechanisms, procedures, forms and unwritten rules existing in the company, used as means to build temporary, informal forms and components of the organizational structure". In turn, Baker and others (Baker, Miner, Easley 2003; Baker, Nelson 2005, Steffens, Senyard, Baker 2009) interpret bricolage as:

- an existing network of social contacts used as means used to construct the company architecture (Baker, Miner, Eesley 2003);

- $\quad$ creating from current resources (meaning tools and materials available at hand) new products or services (Baker, Nelson 2005);

- $\quad$ the process of using and changing the currently owned resources through using or combining them once again or differently (Steffens, Senyard, Baker 2009).

Zahra, Gedajlovic, Neubaum, Shulman (2009) show that bricolage describes behaviors of businessmen who, by acting locally, discover the possibilities of local resources. The significance of limited resources in connection with the ability to improvise by the members of the organization are in this process stressed out by Di Domenico, Haugh, Tracey (2010). However in Gundry's (Gundry et al. 2011) work bricolage is presented as a distinctive concept connecting a creative adaptation and manipulating resources such as materials, finances and human resources (Sipa 2011), in order to solve problems or take advantage of new possibilities. Already a casual overview of the bricolage definitions in literature in terms of management, indicates that two key features of the process are stressed in them, and namely - what can be done with the currently owned resources and what possible recombination of these resources is possible in order to achieve new goals. Furthermore, it stresses out that bricolage refers to identifying the solution (solutions) of the problem, mainly through experimenting (often connected to improvisation), and concerns combining existing resources with the use of easily available skills and using existing capabilities. As Ciborra (2002) points out, bricolage may be treated as a form of practical intelligence, displayed in the way people reorganize their resources in the event of unexpected circumstances. The resources mentioned in the context of defining bricolage cover a wide spectrum of company assets: they mean both material and immaterial resources (capabilities, competences, processes, information, knowledge) which may be used to execute a strategy and build added value (Powell, Sandholtz 2012). Therefore, bricolage may take on different forms and find application in various fields of the company's activity, including risk management (Gorzeń-Mitka 2016).

The bricolage concept undoubtedly offers a potential for a better understanding of organizational resourcefulness, including the author's opinion in reference to forming the company culture in risk conditions (the so called risk culture, risk management culture) (Gorzeń-Mitka, 2015b). The study includes the research results concerning the identification of correlations between bricolage and the attitude as to risk as a key element of forming the risk management culture in the practice of Polish small and medium sized enterprises from the point of view of a balanced development (Gorzeń- 
Mitka 2016). An additional goal of this research is to, at least partially, fill the gap in researches in terms of risk management. The research findings indicate that an approach to decision processes in the context of bricolage and an attitude towards risk are indeed dependent of one another.

\section{Bricolage research in the field of management - key trends}

Management research (especially in the scope of entrepreneurship) often defines bricolage as a functional concept applied by companies lacking resources (Garud, Karnoe 2003). This is determined by the fact that it is only such entities that begin to transform currently unused resources (also for purposes other than originally intended) because of, among others, their lower usability (value). It is described as so-called forced bricolage. Further in the chapter, several leading trends in bricolage in management are described.

The first of such trends relates to research on the use of bricolage in an organisation. Among sothers, Perkmann's and Spicer'a (2014), dedicated to the subject of start-ups, introduces the term of so-called organisational bricolage, understood as a process in which a new developing organisation searches for and adapts various organisational forms currently found in its surroundings for its own purposes. The proprietary organisational bricolage model presented assumes that the organisational form selection should be made on the basis of two criteria: the founders' experience to date relating to the functioning of various organisational forms and adjustment (or maladjustment) of those forms to the set of values or system of believes adopted by the company, relating to the fulfilment of its goals.

Bricolage is also presented as a way of mobilising resources in a company (Basu, Desa 2013). It is seen as a process supplementary to optimisation processes, which is especially apparent when it comes to critical resources. In terms of resource theory, bricolage is described as a way of operation of entities concerned about their excessive dependency on strong resource suppliers, as it enables them to search for alternative resources (means, substitutes), which can be used in their activity. Another trend in bricolage research is studies on the usability of this concept in driving innovation (Skibiński, Sipa 2015). Research in this scope includes, among other, Baker's work (Baker, Nelson 2005). Especially in study „Creating Something from Nothing: Resource Construction through Entrepreneurial Bricolage" highlights bricolage elements that drive innovation on various operational levels, for example in the scope of technical solutions, work organisation, customer services, skill acquisition and legal measures. Whereas another one of his works written in cooperation with Miner and Eesley (2003), stresses the close relationship between the concept of bricolage and improvisation (some researchers even talk about bricolage improvisation). The authors claim that bricolage plays a key role in improvisation and that those processes are intertwined with entrepreneurship processes (often initiated by the founders). They describe bricolage as a promising concept, in theory and practice, for researching entrepreneurship. Whereas some of the latest research in this scope, presented by Gurca and Ravishankar (2015) in the work entitled A bricolage perspective on technological innovation in emerging markets, is dedicated to analysing bricolage as a strategy which facilitates development of affordable, innovative and 
technologically advanced products by companies with limited resources and minimal equity investments. It proves that many forms of bricolage can be implemented and used in management on the organisational and inter-organisational level. Moreover, it shows that bricolage, which is usually seen as a characteristic feature of behaviours and skills which enable entrepreneurs and innovators to fulfil their tasks even in challenging conditions, can be carefully planned and executed as a strategy supporting innovation. The authors suggest that a cost-effective bricolage strategy may support the development of newly established enterprises.

The use of bricolage in the scope of technical and technological solutions was also analysed in the works of Garud's and Karnoe's (2003). While describing the results of their comparative analysis of the processes of establishing wind farms in Denmark and the United States, they suggest that bricolage can be used, on the one hand, for finding opportunities (new solutions) in crisis situations, and on the other hand, for creating new opportunities through teamwork. They claim that by establishing cooperation on various levels of interaction (between designers and vendors, manufacturers and users, scientists and external manufacturers, and finally between political decision-makers and the market), even less technologically advanced projects (Danish wind farms) may achieve higher efficiency in regard to more advanced projects (American wind farms). The prerequisite for achieving higher efficiency is having and using various connections supporting mutual involvement of cooperating entities. Technological initiatives not based on this kind of cooperation stimulate skills and resources on lower efficiency levels.

With regard to the issue of risk and uncertainty, bricolage is assessed, among others, by Senyard, Baker and Davidson (2009). While considering bricolage in the context of an organisation's efficiency and innovation potential, they stress that a large share of bricolage activities in its operation results in a high level of unpredictability and uncertainty of its actions (especially in case of small entities). If it is also connected to other risk sources, it may create a high level of strategic risk for the company. With regard to the issue of risk and its connection to bricolage, it is advisable to refer to Weick's study results (1993). He claims that bricolage may not only generate risk in certain situations, but also influence the development of the organisation's resistance to risk. It is because bricolage enables the organisation to overcome crisis situations by developing an ability to take actions and to search for solutions in unusual situations with the use of typical, available, limited resources. Awareness of the components of a bricolage working environment as well as ongoing use and permutation of those components in the bricolage process gives the organisation the ability to act in unusual situations, such as a crisis. Whereas the lack of a paralysing effect of the unusual situation facilitates direct involvement in the process of searching for a solution to the crisis. A characteristic group of risk in this scope is risk corresponding to sustained development. According Dan R. Anderson (2007) Sustainability Risk. Management as a Critical Component of Enterprise Risk Management: Global Warming - Climate Change Risks sustainability risks will be one of the most critical risk areas impacting businesses and society in the 21 st century. Sustainability risk management needs to be a critical component of Enterprise Risk Management (ERM) strategies. 
Taking account of the above, it appears advisable to commence research on the link between bricolage and the risk management culture, which constitutes the main component of effective risk management from the integrated perspective. Further in the paper, the main conclusion from the author's own research on the relation between bricolage and attitudes towards risk is presented as the main determinant of the place of risk in organisational culture.

\section{Method and results}

Identification of perception of bricolage in risk context was performed during the study which aimed to analyze risk management trends in small, medium and large enterprises in Poland. Purposive sample was used for the study. The study was conducted in first half of 2015 on a sample of 157 companies categorized, according to the number of employees, as small, medium and large enterprises. The survey questionnaire was addressed to both manufacturing, trade and service enterprises. Questionnaires were sent to owners of businesses and people responsible for risk management in companies. An assumption was made that their attitude towards risk largely determines the approach to the specified manifestations of bricolage. The main characteristics of the study sample are presented in Tables 1-2.

Table 1. Characteristic of the study sample - descriptive statistics

\begin{tabular}{|l|l|l|l|l|}
\hline FEATURES & $\begin{array}{l}\text { Number of years of } \\
\text { operation in the market }\end{array}$ & Sompany size & Sector & $\begin{array}{l}\text { Main area } \\
\text { of activity }\end{array}$ \\
\hline Average & 2,1720 & 2,1847 & 1,2484 & 1,6752 \\
\hline Median & 2,0000 & 2,0000 & 1,0000 & 1,0000 \\
\hline Dominant & 2,00 & 2,00 & 1,00 & 1,00 \\
\hline Standard deviation & 0,69962 & 0,42095 & 0,43347 & 0,77804 \\
\hline
\end{tabular}

Source: own study

Table 2. Characteristic of the study sample - frequency table

\begin{tabular}{|l|l|l|l|}
\hline FEATURES & Frequency & Percent \\
\hline \multirow{2}{*}{$\begin{array}{l}\text { Number of years of operation } \\
\text { in the market }\end{array}$} & $1-5$ years & 130 & 82,8 \\
\cline { 2 - 4 } & $5-10$ years & 25 & 15,9 \\
\cline { 2 - 4 } & $>10$ years & 2 & 1,3 \\
\hline \multirow{3}{*}{ Mector } & private & 118 & 75,2 \\
\cline { 2 - 4 } & public & 39 & 24,8 \\
\hline \multirow{3}{*}{ Main area of activity } & production & 81 & 51,6 \\
\cline { 2 - 4 } & trade & 46 & 29,3 \\
\cline { 2 - 4 } & service & 30 & 19,1 \\
\hline Company size & small $(10-49)$ & 119 & 75,8 \\
\cline { 2 - 4 } & medium $(50-249)$ & 29 & 18,5 \\
\cline { 2 - 4 } & large $(>250)$ & 9 & 5,7 \\
\hline Total & & 157 & 100,0 \\
\hline
\end{tabular}

Source: own study 
Small businesses dominated the sample, accounting for $75 \%$ of all surveyed companies. The largest group of companies, at $82,8 \%$, have been operating in the market 1 - 5 years. The study used a questionnaire concerning bricolage by Senyard, Baker and Davidsson (2009) published in the Entrepreneurial Bricolage: Towards Systematic Empirical Testing.

The following research hypotheses were proposed with the main aim of the project in mind:

H1 - perception of the bricolage in a company depends on risk attitude perspective;

In this case, we proposed eight complementary hypotheses:

H1.1. - perception of ability to find workable solutions to new challenges by using existing resources in the organisation depends on risk attitude perspective.

H1.2. - tendency to take on a broader range of challenges than others depends on risk attitude perspective.

H1.3. - opinion that to use any existing resource that seems useful to responding to a new problem or opportunity depends on risk attitude perspective.

H1.4. - opinion that deal with new challenges by applying a combination of existing resources and other resources inexpensively available to company depends on risk attitude perspective.

H1.5. - opinion that, having to deal with new problems or opportunities action are taken, assuming that we will find a workable solution, depends on risk attitude perspective.

H1.6. - combination of existing resources, to respond to a variety of new challenges, depends on risk attitude perspective.

H1.7. - search practical solutions in new challenges based on existing resources, depends on risk attitude perspective.

H1.8. - ability to connect resources in a different way than their original purpose, depends on risk attitude perspective.

Table 3 shows the descriptive statistics related to the evaluation of the perception of bricolage in an organization in the context of attitude towards risk.

Table 3. Perception of bricolage characteristics - descriptive statistics

\begin{tabular}{|l|l|l|l|l|}
\hline & & & & \\
& & & & \\
& & & \\
\hline $\begin{array}{l}\text { P1. We are confident of our ability to find workable solutions to } \\
\text { new challenges by using our existing resources. }\end{array}$ & 2,4650 & 2,0000 & 3,00 & 0,92354 \\
\hline $\begin{array}{l}\text { P2. We gladly take on a broader range of challenges than others } \\
\text { with our resources would be able to. }\end{array}$ & 2,4968 & 2,0000 & 2,00 & 0,91724 \\
\hline $\begin{array}{l}\text { P3. We use any existing resource that seems useful to } \\
\text { responding to a new problem or opportunity. }\end{array}$ & 2,1338 & 2,0000 & 2,00 & 0,87042 \\
\hline $\begin{array}{l}\text { P4. We deal with new challenges by applying a combination of } \\
\text { our existing resources and other resources inexpensively } \\
\text { available to us. }\end{array}$ & 2,5350 & 3,0000 & 3,00 & 0,77235 \\
\hline $\begin{array}{l}\text { P5. When dealing with new problems or opportunities we take } \\
\text { action by assuming that we will find a workable solution. }\end{array}$ & 2,1146 & 2,0000 & 2,00 & 0,95386 \\
\hline
\end{tabular}




\begin{tabular}{|l|l|l|l|l|}
\hline $\begin{array}{l}\text { P6. By combining our existing resources, we take on a surprising } \\
\text { variety of new challenges. }\end{array}$ & 2,3822 & 2,0000 & 2,00 & 1,02241 \\
\hline $\begin{array}{l}\text { P7. When we face new challenges we put together workable } \\
\text { solutions from our existing resources. }\end{array}$ & 2,8089 & 3,0000 & 3,00 & 0,76906 \\
\hline $\begin{array}{l}\text { P8. We combine resources to accomplish new challenges that } \\
\text { the resources weren't originally intended to accomplish. }\end{array}$ & 3,0510 & 3,0000 & 3,00 & 0,79094 \\
\hline
\end{tabular}

Source: own study

Analysis of the survey results has allowed for both a full and partial verification of the hypotheses. Pearson's chi-squared test is the analysis tool for testing study hypothesis (table 2). It was assumed that a probability value at the level of $\mathrm{p}<0,05$ is statistically significant, whereas $\mathrm{p}<0,01$ is statistically highly significant. Attitude towards risk was assessed by identifying approaches of the respondent to risk (i.e. whether they see risk as a positive factor in their activities in the organization - a factor which can generate a potential chance, opportunity, or vice versa, i.e. they consider risk as a generator of danger and has negative connotations).

Table 2. Perception of bricolage characteristics in company from a risk attitude perspective (Pearson's chi-squared test)

\begin{tabular}{|c|c|c|c|c|c|}
\hline \multirow{3}{*}{ Hypothesis } & \multirow{3}{*}{$\begin{array}{l}\text { Verification } \\
\text { of th } \\
\text { hypothesis }\end{array}$} & \multicolumn{4}{|c|}{ Risk attitude } \\
\hline & & \multicolumn{2}{|c|}{ risk $=>$ opportunity $(\mathrm{df}=1)$} & \multicolumn{2}{|c|}{ Risk $=>$ threat $(\mathrm{df}=1)$} \\
\hline & & $\mathrm{Chi}^{\wedge} 2$ & p & $\mathrm{Chi}^{\wedge} 2$ & $\mathrm{P}$ \\
\hline H1.1. & + & $4,184 *$ &, 041 & 2,063 & 0,151 \\
\hline H1.2. & + & $5,136 *$ &, 023 & 3,025 & 0,082 \\
\hline H1.3. & - & 2,050 & 0,152 & 1,068 & 0,301 \\
\hline H1.4. & - & 1,078 & 0,299 & 0,091 & 0,763 \\
\hline H1.5. & + & 2,133 & 0,144 & $4,151 *$ & 0,042 \\
\hline H1.6. & + & $6,798 * *$ & 0,009 & 3,656 & 0,056 \\
\hline H1.7. & + & 2,968 & 0,085 & $4,137 *$ & 0,042 \\
\hline H1.8. & - & 1,114 & 0,291 & 3,086 & 0,079 \\
\hline
\end{tabular}

** Correlation is significant at the level of 0.01 .

* Correlation is significant at the level of 0.05 .

Source: own study

The results in table 2 allow approval of selected complementary hypotheses H1.1.-H1.8. In light of the present study, it can be concluded that perception of bricolage characteristics in a company depends on a risk attitude perspective in selected areas.

The aspects of bricolage featured in the study allowed for the identification of several connections with the attitude towards risk presented by those responsible in the company for issues of risk management. Of the eight auxiliary hypotheses in the case of five the results have confirmed significant statistical relationships between the specified features of the bricolage process and the perception of risk in the organization by its owner or the person responsible for risk management.

The following relationships have been shown: 
- the belief that the resources existing in the company allow for effectively responding to the new challenges faced by the company depends on the perception of risk as an opportunity and chance (H1.1.),

- $\quad$ the belief that the company's employees willingly undertake actions in a broader scope (i.e. beyond their basic responsibilities) depends on the perception of risk as an opportunity and chance (H1.2.),

- $\quad$ the belief that by combining the owned resources it is possible to respond to new challenges depends on the perception of risk as an opportunity and chance (H1.6.), - the belief that when facing new problems (opportunities), actions aimed at practically solving (using) these problems are undertaken in the organization depends on the perception of risk as a threat (H1.5.),

- $\quad$ the belief that the new challenges in the organization stimulate its members to search for practical solutions based on existing resources depends on the perception of risk as a threat (H1.7).

Given that the attitude towards risk is a key element in shaping the risk management culture in an organization, we can assume that there is a connection between the possibilities of using the concept of bricolage in shaping its decision-making processes and its risk culture.

\section{Conclusions}

Bricolage is a concept that is certainly gaining interest among researchers in the field of management as an approach that allows for solving organizational problems and stimulating the opportunities for the development of the organization in conditions of limited resources and uncertainty of environment. A number of studies have shown that there is a variety of areas in which it may be applied (both on the operational and strategic levels). The presented studies have shown associations between selected bricolage characteristics and the attitude towards risk presented by the members of the organization.

\section{References}

Anderson D.R. (2007). Sustainability Risk Management as a Critical Component of Enterprise Risk Management: Global Warming - Climate Change Risks. http://internationalinsurance.org

Baker T., Nelson R. (2005). Creating something from nothing: Resource construction through entrepreneurial bricolage. Administrative Science Quarterly 50, 329-366.

Baker, T., Miner, A. \& Easley, D. (2003). Improving firms: Bricolage, account giving and improvisational competency in the founding process. Research Policy, 32(2), 255-276.

Basu G., Desa S. (2013). Optimization or Bricolage? Overcoming Resource Constraints in Global Social Entrepreneurship. Strategic Entrepreneurship Journal, 7(1), 26-28.

Ciborra, C. U. (1996). The platform organization: Recombining strategies, structures and surprises. Organization Science, 7, 103-118.

Ciborra, C. U. (2002). The Labyrinths of Information: Challenging the Wisdom of Systems. Oxford: Oxford University Press

Desa, G. (2012). Resource mobilization in international social entrepreneurship: Bricolage as a mechanism of institutional transformation. Entrepreneurship Theory and Practice, 36(4) 727-751. 
Di Domenico, M., Haugh, H., \& Tracey, P. (2010). Social bricolage: Theorizing social value creation in social enterprises. Entrepreneurship theory and practice, 34(4), 681-703.

Haviernikova, K. (2014). Qualitative and quantitative aspects of the clusters in the Slovak Republic. Economics And Management, 18(4), 778-792.

Garud R., Karnoe P. (2003). Bricolage Versus Breakthrough: Distributed and Embedded Agency in Technology Entrepreneurship, Research Policy, 32, 277-300.

Gorzeń-Mitka I. (2015a). Bricolage w zarządzaniu organizacją - przegląd wybranych badań (Bricolage in organization management - a review of selected studies) [in:] Determinanty efektywnego zarządzania organizacjami (ed.) Lemańska-Majdzik A., Wydawnictwo Wydziału Zarządzania Politechniki Częstochowskiej, Czestochowa, 17-25.

Gorzeń-Mitka, I. (2015b). Management challenges in the context of risk culture. Problems of Management in the 21 st Century, 10(2), 60-61.

Gorzeń-Mitka I. (2016). Leading Risk Management Determinants of Small and Medium-Sized Enterprises (SMEs): An Exploratory Study in Poland, Eurasian Studies in Business and Economics, 3(1), 289298.

Gundry, L. K., Kickul, J. R., Griffiths, M. D., \& Bacq, S. C. (2011). Entrepreneurial bricolage and innovation ecology: Precursors to social innovation? Frontiers of Entrepreneurship Research, 13:19, 3.

Gurca A., Ravishankar M.N. (2015). A bricolage perspective on technological innovation in emerging markets, 2015. IEEE Transactions on Engineering Management, 63(1), 53-66.

Levi-Strauss C. (1969). Myśl nieoswojona (La pensée sauvage), PWN, wyd. I, Warszawa (polish edition).

Okręglicka, M., Gorzeń-Mitka, I., \& Ogrean, C. (2015). Management Challenges in the Context of a Complex View-SMEs Perspective. Procedia Economics and Finance, 34, 445-452.

Perkmann M., Spicer A. (2014). How Emerging Organizations Take Form: The Role of Imprinting and Values in Organizational Bricolage. Organization Science, 25(6):1785-1806. http://dx.doi.org/10.1287/orsc.2014.0916

Powell, W.W., Sandholtz K.W. (2012). Amphibious entrepreneurs and the emergence of organizational forms. Strategic Entrepreneurship Journal, 6(2), 94-115;

Sarasvathy, S.D. (2001). Causation and effectuation: Towards a theoretical shift from economic inevitability to entrepreneurial contingency. Academy of Management Review, 26(2), 243- 288.

Senyard J., Baker T. and P. Davidsson (2009), Entrepreneurial Bricolage: Towards Systematic Empirical Testing. Frontiers of Entrepreneurship Research, 29(5).

Sipa, M. (2011). Specyfika działalności małych przedsiębiorstw o zróżnicowanym poziomie innowacyjności i konkurencyjności. Zeszyty Naukowe Uniwersytetu Szczecińskiego, 638, 441-448.

Skibiński A., Sipa M. (2015) Sources of Innovation of Small Businesses: Polish Perspective. Procedia Economics and Finance, 27, 429-437.

Steffens, Senyard, \& Baker (2009). Linking resource acquisition and development processes to resourcebased advantage: bricolage and the resource-based view. In: 6th AGSE International Entrepreneurship Research Exchange, 4-6 Feb. 2009, University of Adelaide, Adelaid.

Weick K.E. (1993). The collapse of sensemaking in organizations: The Mann Gulch disaster. Administrative Science Quarterly, 38.

Zahra, S. A., Gedajlovic, E., Neubaum, D. O. \& Shulman, J. M. (2009). A Typology of Social Entrepreneurs: Motives, Search Processes and Ethical Challenges. Journal of Business Venturing, 24, 519-532. 